Araştırma Makalesi - Research Article

\title{
Glikoz/Hava Enzimatik Yakıt Hücresi Kullanılarak Tek Çip Üzerinde Glikoz Tayini
}

\author{
Samet ŞAHIN ${ }^{1,2^{*}}$ \\ Geliş / Received: 09/10/2019 \\ Revize / Revised: 30/10/2019 \\ Kabul / Accepted: 30/10/2019 \\ $\overline{\mathbf{o z}}$ \\ Diyabet hastalığı, kronik ve metabolik bir rahatsızlık olup günümüzde birçok insanın yaşam kalitesini \\ etkilemekte ve giderek büyüyen bir sorun haline gelmektedir. Bu nedenle kandaki glikoz miktarının takip \\ edilmesi ve belirlenmesi diyabet tanısı için büyük öneme sahiptir. Bu çalışmada, glikoz/hava enzimatik yakıt \\ hücresi kullanılarak kendi kendine çalışabilen bir glikoz tayin çipi geliştirilmiştir. Enzimatik yakıt hücresinin \\ anodu ferrosen-nafyon içeren çok duvarlı karbon nanotüpler ile modifiyeli elektrotlara glikoz oksidaz enziminin \\ tutuklanmasıyla; katodu ise, asitle muamele edilmiş tek duvarlı karbon nanotüple modifiyeli elektrotlara \\ bilirubin oksidaz enziminin tutuklanmasıyla hazırlanmıştır. Hazırlanan anot ve katot sırasıyla glikoz ve oksijen \\ substratları kullanılarak elektrokimyasal olarak karakterize edilmiştir. Tek çip üzerinde hazırlanan enzimatik \\ yakıt hücresi 0-3 mM glikoz konsantrasyonu aralığında lineer sonuç vererek $33 \mathrm{mV} / \mathrm{mM}$ hassasiyetinde glikoz \\ tayini sağlamış ve 30 saniye gibi kısa bir sürede sonuç vermiştir.
}

Anahtar Kelimeler- Biyosensör, Glikoz Oksidaz, Bilirubin Oksidaz, Enzimatik Yakıt Hücresi, Diyabet

${ }^{1 *}$ Sorumlu yazar iletişim: samet.sahin@bilecik.edu.tr (https://orcid.org/0000-0002-0568-4283)

Biyomühendislik, Mühendislik Fakültesi, Bilecik Şeyh Edebali Üniversitesi, 11230 Bilecik, Türkiye

${ }^{2}$ Biyoteknoloji Uygulama ve Araştırma Merkezi, Bilecik Șeyh Edebali Üniversitesi, 11230 Bilecik, Türkiye 


\title{
A Self-Powered Detection of Glucose Using Glucose/Air Enzymatic Fuel Cell on a Single Chip
}

\begin{abstract}
Diabetes is a chronic and metabolic disorder that affects many people's quality of life and is becoming a growing problem. Therefore, monitoring and determining the amount of glucose in the blood is of great importance for the diagnosis of diabetes. In this study, a self-powered glucose determination was developed using glucose/air enzymatic fuel cell (EnFC) on a single chip. The anode of the EnFC is prepared by immobilizing glucose oxidase enzyme on ferrocene-nafion containing multi-walled carbon nanotube modified electrodes; the cathode, on the other hand, was prepared by immobilizing bilirubin oxidase enzyme on acid-treated single-walled carbon nanotube modified electrodes. The prepared anode and cathode were electrochemically characterized using glucose and oxygen substrates respectively. EnFC prepared on a single chip showed a linear response in the range of 0-3 mM glucose concentrations, achieving $33 \mathrm{mV} / \mathrm{mM}$ sensitivity and a response time of 30 seconds.
\end{abstract}

Keywords-Biosensor, Glucose Oxidase, Bilirubin Oxidase, Enzymatic Fuel Cells, Diabetes 


\section{INTRODUCTION}

The detection of specific biomolecules (e.g. glucose) plays an important role in the diagnosis and monitoring of diseases. Furthermore, the development of a stable, cost-effective and reliable measuring system is of great importance in the medical, environmental and industrial fields [1]. Because of their fast response times, high sensitivity, high specificity, and accuracy, electrochemical biosensors are often preferred as a useful tool for the detection of such molecules [2]. Furthermore, these devices also stand out because of their suitability for miniaturization in the development of measurement systems that can be applied at the bedside and in daily life [3].

Sensitive measurement of glucose molecule is especially important for diabetic patients and recently many studies have been carried out in the literature. The most successful glucose biosensors used today are electrochemical based and they are mainly classified into two main groups, enzymatic and non-enzymatic [1]. The most common enzyme used in enzymatic biosensors is glucose oxidase (GOx) [4]. In non-enzymatic sensors, different metals such as platinum, gold and copper and recently nanomaterials are often used [5]. Electrochemical enzymatic biosensors can generally be divided into three groups. The first group of glucose sensors is based on the measurement of hydrogen peroxide released by enzymatic oxidation of glucose using amperometric methods [5]. Such biosensors have some disadvantages because they are oxygen-dependent, work at high potential, and interact with other molecules in the blood (such as uric acid, ascorbic, etc.). The second group of biosensors contains an enzyme that oxidizes glucose, as well as a redox mediator. These redox mediators reduced the effect of oxygen by capturing the electrons released from the oxidation reaction. The most important problem in this type of biosensor is that the performance of the sensor depends on multiple parameters so that the electrode configuration must be carefully selected. Finally, the third group of biosensors is the systems in which the electron transfer between the enzymes used and the electrodes is carried out by the enzyme itself. To develop such biosensors, enzymes should have their active centers near the surface of the protein shell or the enzymes must undergo some mutations [6-8]. However, these types of biosensors perform poorly among existing systems due to the measurement limit ranges.

Since the enzymatic fuel cell (EnFC) first appeared in 1964, it has continued to develop until today [9]. It is also thought that even NASA can benefit from the idea of converting organic waste into energy, such as using an implantable micro-power source or as a power source for microelectronic devices [10]. However, such fuel cells could not compete with chemical fuel cells due to performance, life and stability problems. The working principle of EnFCs is the same as that of conventional fuel cells but uses enzymes as catalysts. The electrons released as a result of enzymatic oxidation of the fuel (as a substrate) in the anode reach the cathode by an electronic circuit, and the product (usually water) is formed by the enzymatic reduction reaction (e.g. oxygen reduction) that occurs here [11]. This results in a potential difference between the two electrodes (anode and cathode).

Glucose/Air fuel cells are the most commonly used EnFCs because it is possible to make blood-fueled fuel cells using glucose and oxygen, which are readily available in the blood. Moreover, glucose/air EnFCs have recently been tested in applications such as biosensors that can provide their power in determining the amount of glucose [12]. The first example of such an application was reported in 2001 by Katz et al. [13]. This type of biosensor is based on the principle that the voltage difference between the anode and cathode changes according to the amount of glucose contained in the fuel cell. The most commonly used anode and cathode enzymes in this type of fuel cell are GOx and bilirubin oxidase (BOD) [14].

Compared to conventional biosensors, EnFC-based biosensors provide many advantages. These advantages can be listed as;

1- A simplified electronic system since no potentiometer is required,

2- Since it is a system with two electrodes instead of three, easier miniaturization and application,

3- A more stable structure since it is not connected to a reference electrode,

4- It is possible to produce cheaper sensors with printed circuit electrodes [10] 
Different approaches were developed for self-powered EnFCs such as substrate-based (due to the sensitivity of the enzyme to change in substrate concentration), inhibition-based (due to the sensitivity of the enzyme to change in inhibitor concentration) and the enzyme-based (EnFCs sensitive to enzyme concentration similar to substrate effect) [15]. The most commonly used of these are EnFCs based on substrate-based EnFCs.

Micro-needle (mostly for wearable biosensor applications) [16], microfluidic [17], and printed circuit electrodes [18] were used to develop EnFCs for measuring glucose. These studies aim to measure glucose in human blood at 3-8 $\mathrm{mmol} / \mathrm{L}$, as well as to measure glucose in hyperglycemia and hypoglycemia. However, although the studies provide results in a certain sensitivity and measurement range, improvements are needed in the stability of the developed electrodes. As a result, the material to be used and the polymeric structures that will increase the stability of the sensor should be systematically studied and electrode characteristics should be determined. In this context, systems that can be applied at the bedside and make the existing technology more useful, ergonomic and simple should be developed. Recently, many EnFC-based glucose biosensors work on substrate action [12, 19-21]. However, although there are different studies, there is still a need for more improvement.

Many electron transfer mediators have been used for glucose biosensors developed for decades. The most important of such mediators are ferrocene $(\mathrm{Fc})$ and its derivatives, osmium and benzoquinone [11]. Fc and its derivatives stand out among others due to their lack of toxins and their easy solubility in different solvents $[22,23]$. Many different methods have been used to develop enzyme electrodes using Fc, studies with Fc-Nafion structures have shown good results [24]. Despite the good results, the problems associated with the low electrical conductivity and long-term use of the formed electrodes are the major obstacles to the commercial production of these devices.

In our recent studies, Fc-Nafion structures have been supported by carbon nanotubes (CNTs), and electrodes have been tested in EnFCs [25]. CNTs have improved the performance of the system using Fc-Nafion with its biocompatible and excellent electrical conductivity. In the system used, Fc was inserted into the Nafion by electrostatic bonding using electrochemical methods and then the GOx enzyme was immobilized using a chemical crosslinking method to form a strong $\pi-\pi$ interaction on the walls of CNTs. In this study, a similar approach was used to construct a self-power biosensor using GOx and BOD for the glucose oxidation reaction and oxygen reduction reaction, respectively. The electrochemical characterization of GOx and BOD has been investigated and the EnFC performance and biosensor characterization was performed. It was shown that such a system could be useful for the detection of glucose, especially for hypoglycemia cases.

\section{MATERIALS AND METHOD}

\section{A. Materials}

All chemicals and enzymes used in this study were obtained from Sigma-Aldrich and used as received without further modification unless otherwise stated. Carbon Duo-Screen-Printed electrodes (SPE, Model: DRPC1110) were purchased from Dropsens, Oviedo, Spain. SPE consists of a reference electrode (silver/silver ion (Ag/Ag+), $74 \mathrm{mV}$ vs SHE, data is obtained from the manufacturer), a carbon counter electrode and dual carbon working electrode. The dimensions of the SPE electrode are 33 x 10 × $0.5 \mathrm{~mm}$ (Length $\mathrm{x}$ Width $\mathrm{x}$ Height) respectively. Electrodes were stored at room temperature in a dry place and no pre-treatment was applied.

\section{B. Fabrication of Anode and Cathode}

The procedure for anode preparation is previously published elsewhere [25]. Briefly, Fc-NafionMWCNTs solution ( $1 \mathrm{mg} / \mathrm{ml}$ nanomaterial, $25 \mathrm{mM} \mathrm{Fc,} 1 \mathrm{wt} \%$ Nafion in $90 \%$ Ethanol) was first drop coated on the working electrode of SPE to yield $0.06 \mathrm{mg} / \mathrm{cm} 2$ material loading. After drying at room temperature, the electrode was pre-treated using cyclic voltammetry $(\mathrm{CV})$ at $50 \mathrm{mV} / \mathrm{s}$ between $-0.4-0.4 \mathrm{~V}$ (vs Ag/Ag+) for 10 cycles. The electrode then washed and dried at room temperature. Immobilization of GOx enzyme was achieved by treating the Fc-Nafion-MWCNTs modified SPEs with 1-Pyrenebutyric acid N-hydroxysuccinimide ester (10mM in dimethylformamide) for $40 \mathrm{mins}$ and then incubating with $10 \mathrm{mg} / \mathrm{ml} \mathrm{GOx}$ solution at $4{ }^{\circ} \mathrm{C}$ for $2 \mathrm{~h}$. 
Finally, the electrode is rinsed with $0.1 \mathrm{M}$ phosphate buffer (PBS) to remove weakly bounded enzymes and used without further treatment. The cathode was prepared using a similar enzyme crosslinking approach without the need of any pre-treatment step. Briefly, the electrodes were first coated with acid-treated singlewalled CNTs (cut-SWCNTs). These cut-SWCNTs were prepared and the optimum material loading was chosen as $0.15 \mathrm{mg} / \mathrm{cm} 2$. Cut-SWCNTs coated SPEs were dried at room temperature and BOD enzyme was immobilized using pyrene-crosslinking chemistry at the same conditions with the anode.

\section{Electrochemical and Fuel Cell Characterization}

All electrochemical measurements were carried out using $0.1 \mathrm{M}$ PBS at pH 7.4 unless otherwise stated using Ivium potentiostat-galvanostat (Ivium Technologies B.V., Netherlands). The stock solution of glucose was allowed to mutarotate for minimum $24 \mathrm{~h}$ before use and was subsequently kept refrigerated at $4^{\circ} \mathrm{C}$. Fuel cell characterization tests were performed using a resistor box (Model: RBox-408 range: $1 \Omega-10 \mathrm{M} \Omega$ ) from Lutron, USA to apply load. The output voltage was recorded via data logger (Model: ADC 24 from Pico Technology, UK). The current and power of the fuel cell were then calculated using Ohm's Law. All the measurements were carried out at room temperature. The biosensor calibration curve was obtained by connecting $200 \mathrm{k} \Omega$ resistance to the EnFC circuit and corresponding cell voltage was recorded for various glucose concentrations.

\section{RESULTS AND DISCUSSION}

\section{A. Anode Characterization}

Incorporation of MWCNTs into Fc-Nafion films has been demonstrated previously to improve the electrical conductivity for better electron transfer and to increase the surface area for enzyme immobilization [25]. Figure 1 shows the pre-treatment step of the Fc-Nafion-MWCNTs coated SPE $(0.06 \mathrm{mg} / \mathrm{cm} 2 \mathrm{material}$ density) at $50 \mathrm{mV} / \mathrm{s}$ scan rate in $0.1 \mathrm{M} \mathrm{PBS}$ at $\mathrm{pH}$ 7.4. Increasing current values with the increasing number of scans indicate the migration of positively charged Fc accumulating into the negatively charged sulfonate groups of Nafion. This type of response is in parallel with the results in the literature [26, 27].



Figure 1. Pre-treatment of Fc-Nafion coated (coating amount $=0.06 \mathrm{mg} \mathrm{cm}-2) \mathrm{SPE}$ at $50 \mathrm{mV} / \mathrm{s}, \mathrm{pH} 7.4(20 \mathrm{cycles}$ of CV applied)

In addition to improved electrical conductivity and enhanced surface area, one of the other advantages of the pre-treatment step is to obtain stable films for enzyme immobilization. Figure 2 shows the performance and standard deviation from the mean of three independently prepared SPEs at different times to test the reproducibility of the Fc-Nafion-MWCNTs coated SPEs. The obtained results show a very little error margin 
between different electrodes which indicates a good degree of reproducibility. Anodic and cathodic peak currents were obtained at $0.085 \mathrm{~V}$ and $-0.13 \mathrm{~V}(\mathrm{vs} \mathrm{Ag} / \mathrm{Ag}+$ ) respectively giving a peak separation value of $45 \mathrm{mV}$ suggesting a reversible electron transfer mechanism [28].

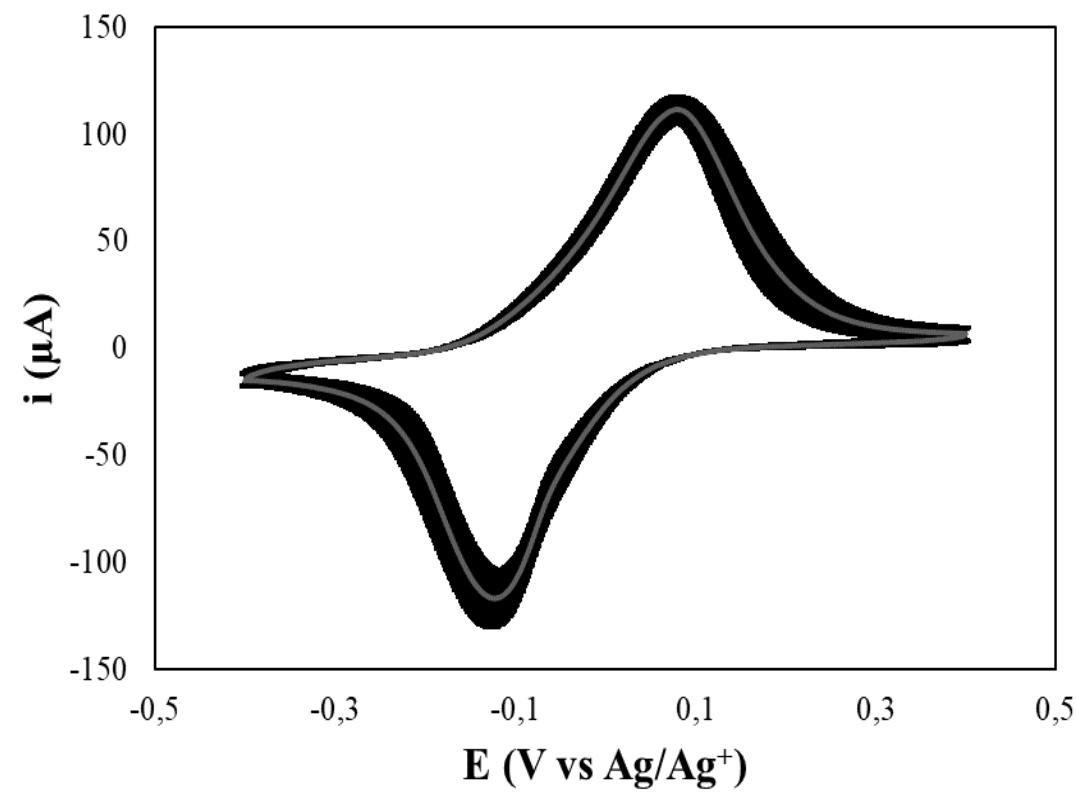

Figure 2. CVs of independently prepared Fc-Nafion-MWCNTs modified SPEs tested in 0.1 M PBS, pH 7.4. (Black error bars are sample standard deviation, $\mathrm{n}=3$ samples)

To demonstrate the enzymatic glucose oxidation reaction using the Fc-Nafion-MWCNTs modified electrode, CVs were applied before and after the GOx immobilization. The current response of the SPEs with and without the immobilization of the enzyme was then compared. Figure 3 (A) shows Fc has direct communication with enzyme before the enzyme immobilization, resulting in definitive peaks, however, after the immobilization procedure, the current response is dramatically decreased. This could be due to the immobilized enzymes on carbon restricting the mobility of ferrocene between the electrolyte and the electrode. Figure 3 (B) also shows a close-up view of the voltammogram regarding the SPE with GOx immobilized. Although small peaks regarding Fc can be seen, the current is reduced by almost 50 folds. 
(A)

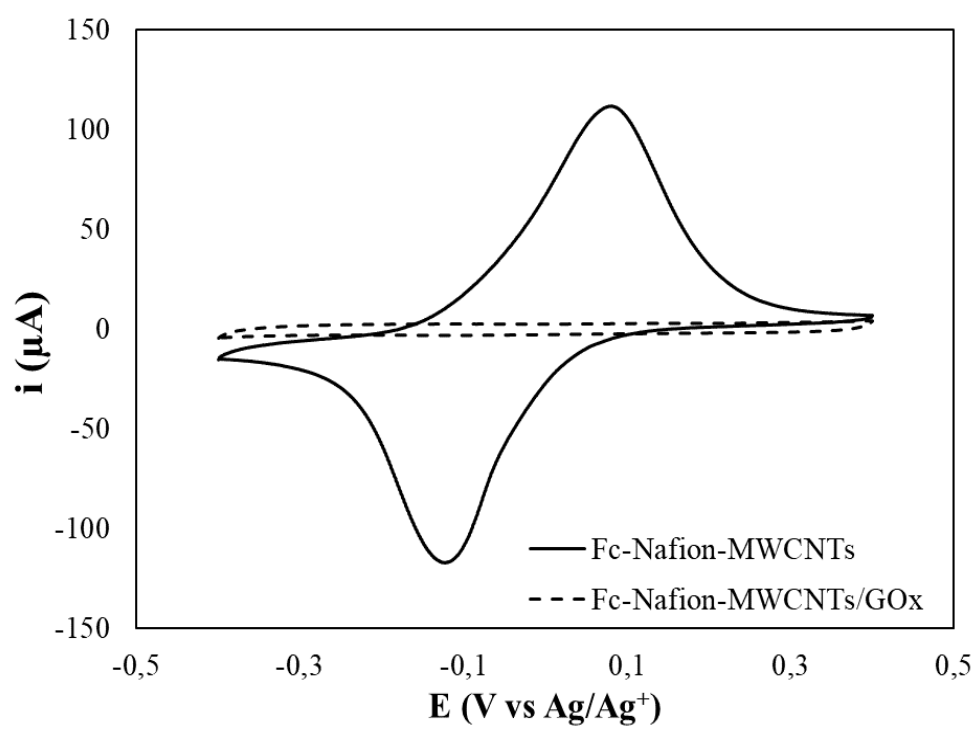

(B)

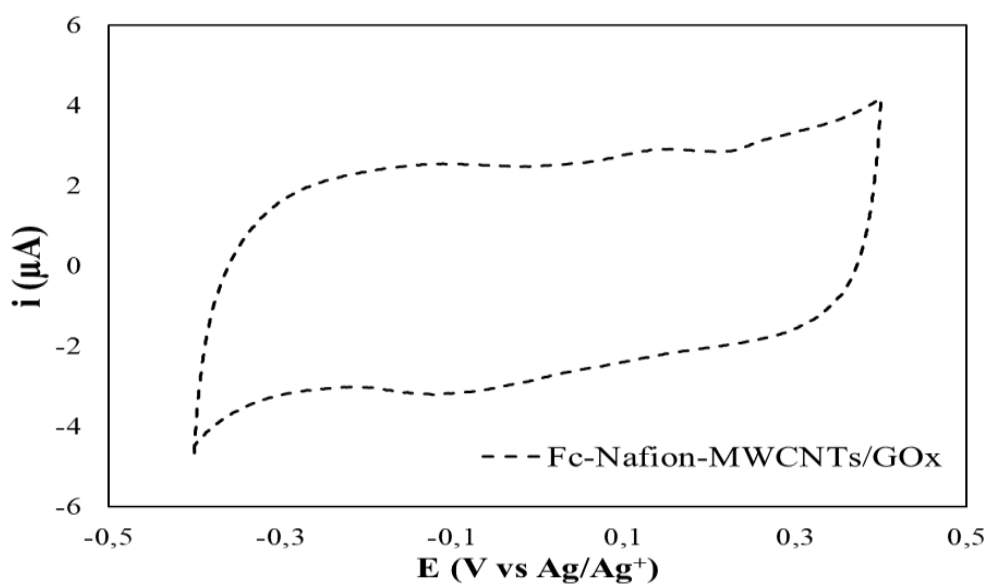

Figure 3. (A) CVs of Fc-Nafion-MWCNTs with and without GOx immobilised and (B) close-up view of the voltammogram for Fc-NafionMWCNTs/GOx, scan rate: $10 \mathrm{mV} / \mathrm{s}$, electrolyte: $0.1 \mathrm{M}$ PBS at $\mathrm{pH}$ 7.4.

Furthermore, Figure 4 demonstrates the current response of GOx immobilized SPEs in the presence of 1 $\mathrm{mM}$ glucose. It can be concluded that the prepared electrode is responsive to glucose due to the enzymatic oxidation of the glucose by the GOx enzyme and the electrons produced are successfully mediated via Fc. The onset potential of $-0.015 \mathrm{~V}$ (vs Ag/Ag+) and peak potential of $0.15-0.20 \mathrm{~V}$ (vs Ag/Ag+) indicates the successful immobilization of the enzyme on the electrode surface and the transfer of electrons via redox mediator. The FcNafion-MWCNTs/GOx on SPE is then proved to be suitable for electrochemical glucose oxidation and hence can be used as an anode in an EnFC. 


\begin{tabular}{|c|c|c|}
\hline & $\begin{array}{l}\text { BŞEÜ Fen Bilimleri Dergisi } \\
6(2), 16-28,2019\end{array}$ & $\begin{array}{r}\text { BSEU Journal of Science } \\
\text { DOI: } 10.35193 / \text { bseufbd.631288 }\end{array}$ \\
\hline $\begin{array}{l}\text { BïLECIKSEYHEDEBAL } \\
\text { ONIVERSITESI }\end{array}$ & & e-ISSN: $2458-7575$ (http://dergipark.gov.tr/bseufbd) \\
\hline
\end{tabular}

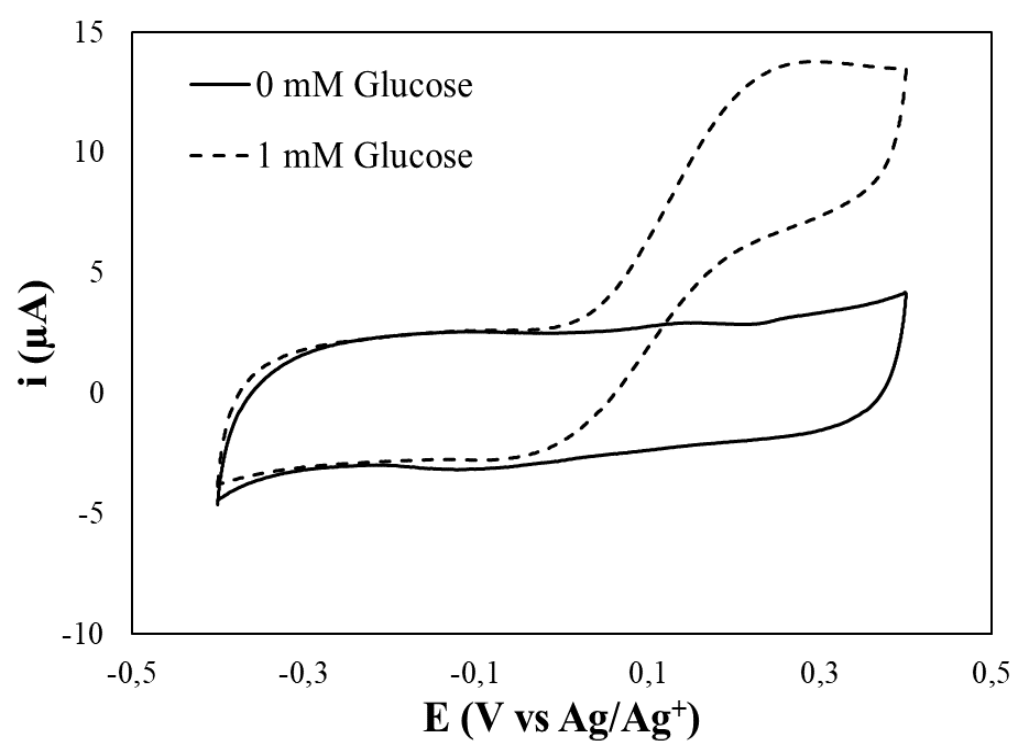

Figure 4. CVs showing the effect of glucose on electrochemical response of Fc-Nafion-MWCNTs/GOx SPEs, scan rate: $10 \mathrm{mV} / \mathrm{s}$, electrolyte: $0.1 \mathrm{M}$ PBS at $\mathrm{pH} 7.4$.

\section{B. Cathode Characterization}

The cathode was prepared using cut-SWCNTs at a material loading of $0.15 \mathrm{mg} / \mathrm{cm} 2$ since it was found to be the most suitable loading without causing any deformations on the electrode surface due to excessive loading of nanomaterial. Figure 5 shows the CVs of CNT modified SPE with and without the immobilized enzyme. It can be seen from the CVs that when BOD was immobilized on the electrode, the current response started to change at around $0.45 \mathrm{~V}$ (vs Ag/Ag+). This voltage value is in parallel with the reported vales of oxygen reduction reaction using the BOD enzyme showing direct communication between the enzyme and electrode has been successfully achieved [29]. The current response is increased about 3-fold when BOD is immobilized on the electrode surface. This suggests that the BOD immobilized cut-SWCNT SPE can electrochemically reduce oxygen and therefore suitable to be used as the cathode in EnFCs.

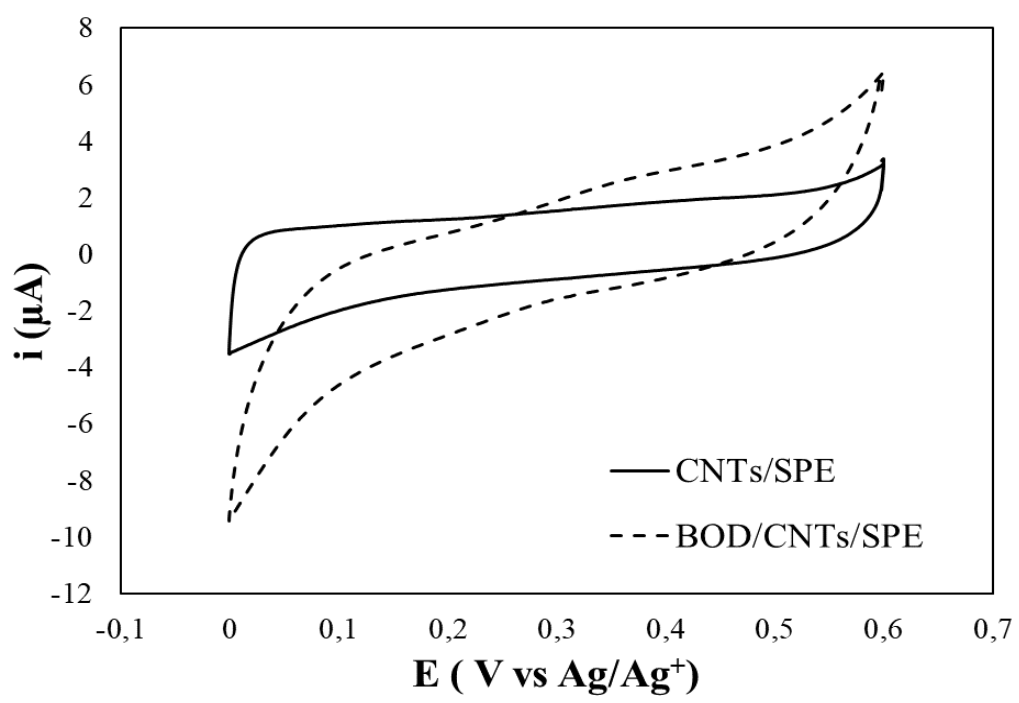

Figure 5. CVs of cut-SWCNT modified SPEs with and without BOD immobilisation, scan rate: $20 \mathrm{mV} / \mathrm{s}$, electrolyte: $0.1 \mathrm{M}$ PBS at pH 7.4. 


\section{EnFC Characterization and Biosensor Performance}

The characterization of the EnFC has been first performed using the anode and cathode developed. First, to determine the working conditions and to determine where the power overshoot occurs, a fuel cell polarization test was conducted. Figure 6 shows the polarization curve of the EnFC prepared using Fc-NafionMWCNTs/GOx anode and cut-SWCNTs/BOD cathode on a dual carbon SPE chip. A solution of $1 \mathrm{mM}$ glucose in $0.1 \mathrm{M}$ PBS at $\mathrm{pH} 7.4$ was dropped on a chip enough to cover both electrodes and polarization was obtained as explained in the methods.

The resistance of the external resistor box was changed from $10 \mathrm{M} \Omega$ to much lower values to find where the power overshoot occurs. Figure 6 shows that after $0.75 \mu \mathrm{A}$ current value, the EnFc power started to show a sharp decrease as well as the cell voltage. It was determined that the power overshoot might have happened at the resistance applied and lower to draw $0.75 \mu \mathrm{A}$ current or more. Therefore, a resistance value of $200 \mathrm{k} \Omega$ is chosen as the lowest resistance to be applied not to harm the EnFC.

The selected resistance value of $200 \mathrm{k} \Omega$ was then used to obtain the calibration curve of the biosensor. The EnFC was connected to $200 \mathrm{k} \Omega$ resistance and the glucose concentration was changed using additionmethod. Figure 7 shows the cell voltage values obtained from the EnFC after $30 \mathrm{sec}$ of exposure to the corresponding glucose concentrations. A linear relationship between 0-3 mM glucose concentrations was obtained with an R2 value of 0.9999 . The sensitivity of the biosensor response was also calculated as 33 $\mathrm{mV} / \mathrm{mM}$. It was shown that a self-powered biosensor can be designed using EnFCs without the need of any external power source. However, the linear range of the biosensor was not exactly at a range desirable for a full diagnosis. On the other hand, the sensor might be useful for the sensitive determination of glucose levels for hypoglycemia cases where patients often have glucose levels less than $3.9 \mathrm{mM}$ [30].

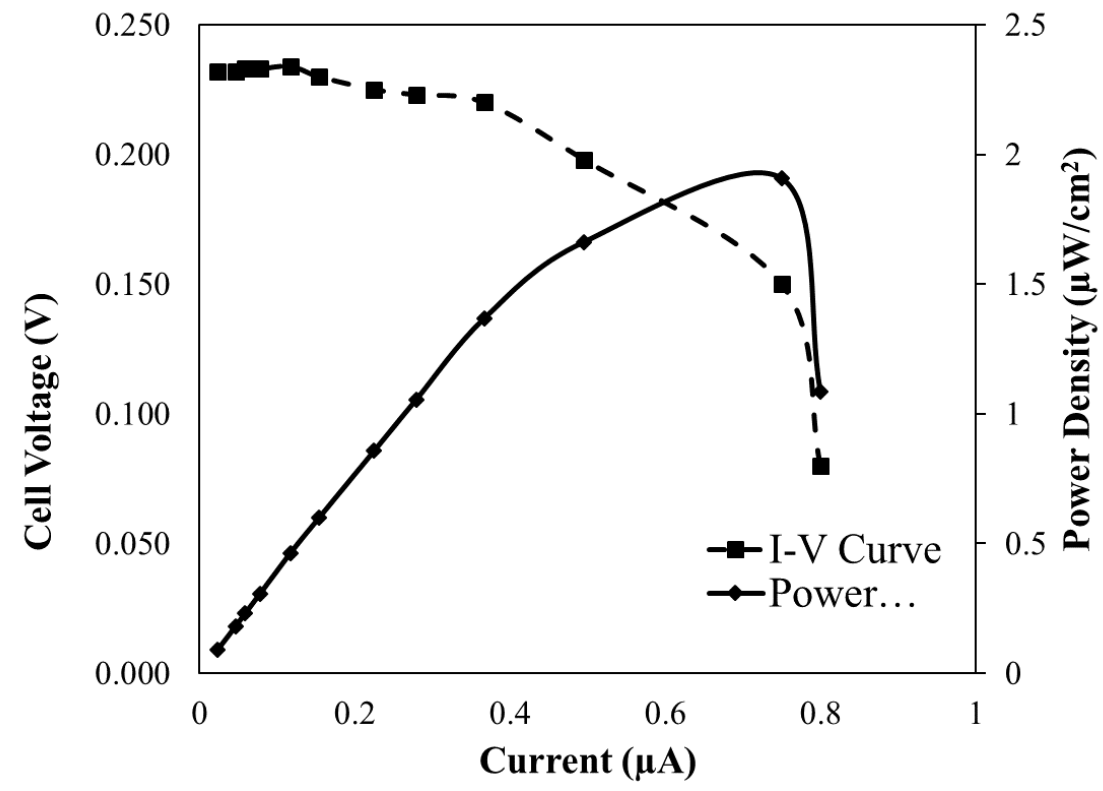

Figure 6. Polarization curve for Fc-Nafion-MWCNTs/GOx anode and cut-SWCNTS/BOD cathode contained EnFC, $1 \mathrm{mM}$ glucose in $0.1 \mathrm{M}$ PBS at $\mathrm{pH} 7.4$. 


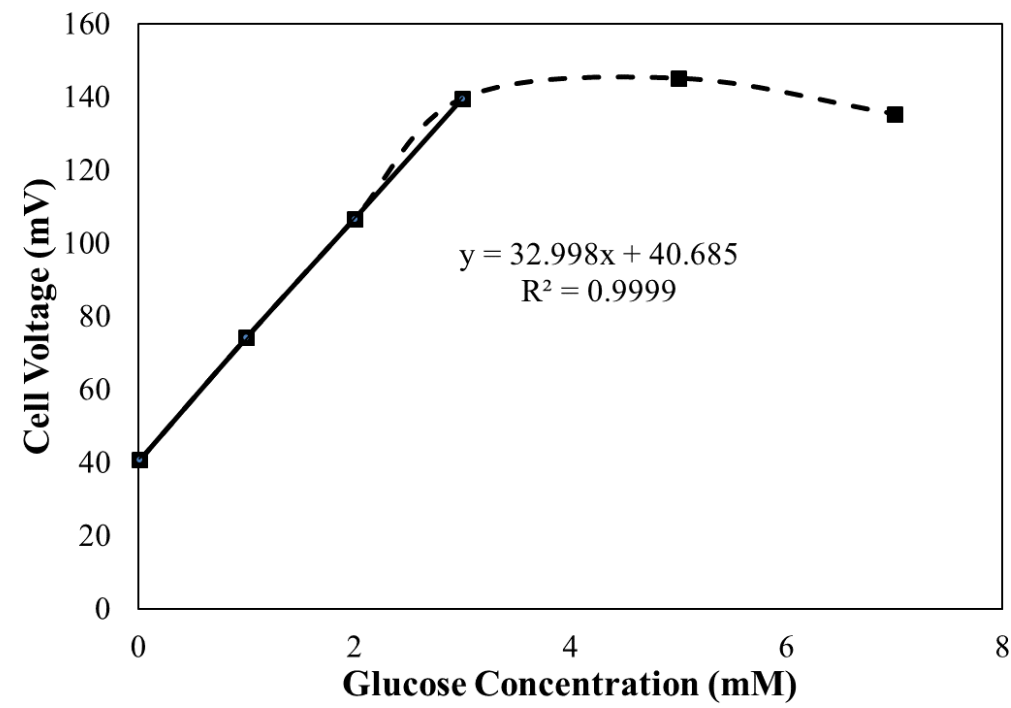

Figure 7. EnFC response to various glucose concentrations in terms of cell voltage tested in 0.1 M PBS at pH 7.4.

\section{CONCLUSION}

In conclusion, a simple and sensitive self-powered glucose biosensor was constructed using a biocompatible approach for electrode fabrication. Fc-Nafion-MWCNTs and cut-SWCNTs were employed for the fabrication of anode and cathode respectively. GOx and BOD enzymes were shown to be effectively working for electrochemical oxidation of glucose and reduction of oxygen respectively. Finally, the EnFC prepared on a single chip showed a linear response in the range of 0-3 mM glucose concentrations, achieving $33 \mathrm{mV} / \mathrm{mM}$ sensitivity and a response time of 30 seconds. The prepared self-powered biosensor can be used in the determination of glucose levels for hypoglycemia cases.

\section{ACKNOWLEDGEMENTS}

This project was supported by the Scientific Research Projects Commission of Bilecik Şeyh Edebali University (Project No: 2018-01.BŞEÜ.03-11, 2019).

\section{REFERENCES}

[1] J. Hovancová, I. Šišoláková, R. Oriňaková, and A. Oriňak, Nanomaterial-based electrochemical sensors for detection of glucose and insulin, Journal of Solid State Electrochemistry, 21 (2017) 2147-2166.

[2] H.A. Abdulbari and E.A.M. Basheer, Electrochemical Biosensors: Electrode Development, Materials, Design, and Fabrication, ChemBioEng Reviews, 4 (2017) 92-105.

[3] E.T.S.G. da Silva, D.E.P. Souto, J.T.C. Barragan, J. de F. Giarola, A.C.M. de Moraes, and L.T. Kubota, Electrochemical Biosensors in Point-of-Care Devices: Recent Advances and Future Trends, ChemElectroChem, 4 (2017) 778-794.

[4] A. Heller, Miniature biofuel cells, Physical Chemistry Chemical Physics, 6 (2004) 209-216.

[5] K. Tian, M. Prestgard, and A. Tiwari, A review of recent advances in nonenzymatic glucose sensors, Materials Science and Engineering: C, 41 (2014) 100-118.

[6] M. Zhang, A. Smith, and W. Gorski, Carbon nanotube-chitosan system for electrochemical sensing based on dehydrogenase enzymes, Analytical Chemistry, 76 (2004) 5045-5050. 
[7] W. Pitsawong, J. Sucharitakul, M. Prongjit, T.-C. Tan, O. Spadiut, D. Haltrich, C. Divne, and P. Chaiyen, A Conserved Active-site Threonine Is Important for Both Sugar and Flavin Oxidations of Pyranose 2Oxidase, The Journal of Biological Chemistry, 285 (2010) 9697-9705.

[8] E.H. Yu, R. Prodanovic, G. Güven, R. Ostafe, and U. Schwaneberg, Electrochemical Oxidation of Glucose Using Mutant Glucose Oxidase from Directed Protein Evolution for Biosensor and Biofuel Cell Applications, Applied Biochemistry and Biotechnology, 165 (2011) 1448-1457.

[9] A.T. Yahiro, S.M. Lee, and D.O. Kimble, Bioelectrochemistry: I. Enzyme utilizing bio-fuel cell studies, Biochimica et Biophysica Acta (BBA)-Specialized Section on Biophysical Subjects, 88 (1964) 375-383.

[10] M. Zhou, Recent Progress on the Development of Biofuel Cells for Self-Powered Electrochemical Biosensing and Logic Biosensing: A Review, Electroanalysis, 27 (2015) 1786-1810.

[11] I. Ivanov, T. Vidaković-Koch, and K. Sundmacher, Recent Advances in Enzymatic Fuel Cells: Experiments and Modeling, Energies, 3 (2010) 803.

[12] M. Grattieri and S.D. Minteer, Self-powered biosensors, ACS sensors, 2017)

[13] E. Katz, A.F. Bückmann, and I. Willner, Self-powered enzyme-based biosensors, Journal of the American Chemical Society, 123 (2001) 10752-10753.

[14] E.H. Yu and K. Scott, Enzymatic Biofuel Cells-Fabrication of Enzyme Electrodes, Energies, 3 (2010) 23.

[15] M. Zhou and J. Wang, Biofuel Cells for Self-Powered Electrochemical Biosensing and Logic Biosensing: A Review, Electroanalysis, 24 (2012) 197-209.

[16] G. Valdés-Ramírez, Y.-C. Li, J. Kim, W. Jia, A.J. Bandodkar, R. Nuñez-Flores, P.R. Miller, S.-Y. Wu, R. Narayan, and J.R. Windmiller, Microneedle-based self-powered glucose sensor, Electrochemistry Communications, 47 (2014) 58-62.

[17] H. Cheng, P. Yu, X. Lu, Y. Lin, T. Ohsaka, and L. Mao, Biofuel cell-based self-powered biogenerators for online continuous monitoring of neurochemicals in rat brain, Analyst, 138 (2013) 179-185.

[18] Z. Liu, B. Cho, T. Ouyang, and B. Feldman, Miniature amperometric self-powered continuous glucose sensor with linear response, Analytical chemistry, 84 (2012) 3403-3409.

[19] J. Halámek, T.K. Tam, G. Strack, V. Bocharova, M. Pita, and E. Katz, Self-powered biomolecular keypad lock security system based on a biofuel cell, Chemical Communications, 46 (2010) 2405-2407.

[20] J. Chen, C. Zhou, H. Liu, P. Li, Y. Song, and F. Xu, Signal Amplification of Self-Potential Biosensor for Glucose Monitoring, Int. J. Electrochem. Sci, 10 (2015) 9142-9153.

[21] M. Zhao, Y. Gao, J. Sun, and F. Gao, Mediatorless glucose biosensor and direct electron transfer type glucose/air biofuel cell enabled with carbon nanodots, Analytical chemistry, 87 (2015) 2615-2622.

[22] J.K. Harkness, O.J. Murphy, and G.D. Hitchens, Enzyme electrodes based on ionomer films coated on electrodes, Journal of Electroanalytical Chemistry, 357 (1993) 261-272.

[23] P. Stepnicka, Ferrocenes: ligands, materials and biomolecules, John Wiley \& Sons, 2008

[24] M. Saleem, H. Yu, L. Wang, A. Zain ul, H. Khalid, M. Akram, N.M. Abbasi, and J. Huang, Review on synthesis of ferrocene-based redox polymers and derivatives and their application in glucose sensing, Analytica Chimica Acta, 876 (2015) 9-25. 
[25] S. Şahin, T. Wongnate, L. Chuaboon, P. Chaiyen, and E.H. Yu, Enzymatic fuel cells with an oxygen resistant variant of pyranose-2-oxidase as anode biocatalyst, Biosensors and Bioelectronics, 107 (2018) 1725.

[26] S. Dong, B. Wang, and B. Liu, Amperometric glucose sensor with ferrocene as an electron transfer mediator, Biosensors and Bioelectronics, 7 (1992) 215-222.

[27] M. Vaillancourt, J. Wei Chen, G. Fortier, and D. Bélanger, Electrochemical and Enzymatic Studies of Electron Transfer Mediation by Ferrocene Derivatives with Nafion-Glucose Oxidase Electrodes, Electroanalysis, 11 (1999) 23-31.

[28] F. Scholz, Thermodynamics of electrochemical reactions, in Electroanalytical Methods. 2010, Springer. p. 11-31.

[29] M.C. Weigel, E. Tritscher, and F. Lisdat, Direct electrochemical conversion of bilirubin oxidase at carbon nanotube-modified glassy carbon electrodes, Electrochemistry Communications, 9 (2007) 689-693.

[30] J.E. Sprague and A.M. Arbeláez, Glucose counterregulatory responses to hypoglycemia, Pediatric endocrinology reviews : PER, 9 (2011) 463-475. 